\title{
Psikoedukasi Parenting dan Kesehatan Mental Secara Online di Masa Pandemi
}

\author{
Krishervina Rani Lidiawati ${ }^{1}$ \\ ${ }^{1}$ Universitas Pelita Harapan \\ krishervina.lidiawati@uph.edu
}

\begin{abstract}
Abstrak
Peran orang tua dalam mendidik dan mengasuh dimasa pandemi Covid-19 ini tentu bukan sesuatu yang mudah. Orang tua berperan mendampingi anak-anak belajar di rumah dan harus tetap fokus bekerja. Selain itu, penting untuk tetap menjaga kesehatan mental keluarga agar tidak mudah cemas dan merasa kelelahan di situasi ini. Tujuan dari penyuluhan ini adalah memberikan pengetahuan dan informasi baru agar dapat mendidik anak di rumah dengan lebih efektif dan tetap menjaga kesehatan mental bersama. Penyuluhan ini dalam bentuk talkshow bekerjasama dengan Yayasan Busur Emas dan radio Heartline radio (100.6FM). Adapun topik yang telah dibahas yaitu pentingnya mendampingi balita bermain, pentingnya pendidikan seksualitas pada anak, jurusan yang tepat: minat anak vs minat orang tua, seni berkomunikasi dengan remaja, waspadai helicopter parenting, mendampingi remaja menghadapi stress di masa pandemi. Manfaat dari kegiatan ini bertambahnya informasi terkait pola asuh dan tips praktis yang berguna bagi orang tua. Hasil dari kegiatan talkshow parenting, adanya antuasias orang tua untuk bertanya baik secara langsung pada saat siaran, permintaan diskusi tema, ataupun pembicaraan terkait tema secara personal, serta permintaan program ini tetap berlangsung. Selain itu, terbentuknya komunitas ngobrol santai tentang kesehatan mental. Program ini melalui Instagram Waktu Indonesia Chatting (WiChat.PSy) bekerjasama dengan psikolog anak di Jerman.
\end{abstract}

Kata Kunci: parenting, kesehatan mental, talkshow

\section{PENDAHULUAN}

Pentingnya kesehatan mental di masa pandemi yang sudah berlangsung lebih dari satu tahun dan masih sedang berlangsung dimulai dari unit terkecil yaitu keluarga. Berperan menjadi orang tua yang baik merupakan harapan bagi sebagian besar pasangan yang telah menikah dan memiliki anak. Relasi orang tua dan anak dapat memengaruhi berbagai aspek kehidupan anak, baik sosial, kognitif, akademis dan nilai-nilai hidup (Ang, Tan, \& Fam, 2016). Tentu dalam pengasuhan kerapkali mengalami berbagai tantangan yang dihadapi dalam merawat, membesarkan serta mendidik anak (Miller
\& Speirs Neumeister, 2017). Apalagi peran orang tua dalam mendidik dan mengasuh dimasa pandemi COVID 19 ini tentu bukan sesuatu yang mudah (Lidiawati, 2020) Hal ini dikarenakan program belajar dari rumah secara online masih berlangsung hingga saat ini. Tanggung jawab orang tua yang mendadak menjadi guru pun bukan sesuatu yang mudah dan membutuhkan kesabaran dalam mendampingi belajar secara online. Banyak orang tua yang mengeluhkan anak-anak mereka kesulitan berkonsentrasi, menjadi kurang termotivasi dalam belajar, cenderung sulit diatur, dan tentunya kondisi rumah tidak kondusif untuk belajar (Lidiawati, 2020). Selain itu, faktor ketersediaan gawai dan 
adanya jaringan koneksi internet juga dapat menambah kendala proses pembelajaran dan kerja di rumah (Lidiawati \& Helsa, 2021)

Keluarga merupakan komunitas terkecil dari masyarakat yang menjadi tempat belajar anak pertama kali. Artinya keluarga sebagai lingkungan pertama yang dikenal anak diharapkan dapat memberi bekal sehingga dapat bertumbuh dan berkembang sesuai dengan tahap perkembangan baik secara fisik, kognitif dan psikososial. Dimasa pandemi ini tentu orang tua memiliki peranan penting untuk menjaga kesehatan fisik anak-anak dan terhindar dari virus Covid 19 dengan tetap belajar di rumah dan memberikan asupan gizi yang baik. Secara kognitif, maka orang tua juga perlu memberikan sarana dan prasarana agar anak tetap lancar belajar di rumah. Namun yang kerapkali dilupakan adalah menjaga kesehatan mental di rumah, baik untuk anak dan orang tua. Padahal berdasarkan penelitian-penelitian terdahulu gaya pola asuh orang tua dapat memengaruhi kesehatan mental pada anak dan remaja secara konsisten dari tahun ke tahun (Ritter, 2005). Selain itu, penelitian lain menunjukkan bahwa parenting style dapat memengaruhi daya lenting atau resiliensi pada anak (Mcintyre \& Member, 2014). Kemampuan ini berkaitan dengan ketrampilannya dalam memecahkan masalah, berpikir kritis, bertahan dalam kesulitan. Hal ini tentu dibutuhkan pada situasi sulit di masa pandemi.

Berbagai tantangan dalam masa pandemi dapat memicu atau mengganggu kesehatan mental. Berbagai tantangan tersebut meliputi berbagai aspek seperti kesehatan fisik, sosial, kondisi keuangan (financial) dan pekerjaan/ pendidikan. Tantangan dalam aspek kesehatan fisik tentu terkait varian virus yang terus bermutasi sehingga orang rentan mengalami kecemasan dan stress. Dalam aspek sosial, kondisi pandemi ini memaksa bekerja, belajar dari rumah dan komunikasi bergantung pada sarana prasarana gawai dan internet. Kondisi gawai yang tidak memadai, koneksi internet yang tidak lancar, listrik padam secara mendadak atau kurangnya melek dengan teknologi pun dapat menjadi pemicu stress. Terkadang orang membutuhkan bersosialisasi dengan orang lain namun jika kurang didukung dengan adanya sarana dan prasarana tersebut tentu akan membuat frustasi atau kesepian karena menjadi kurang mampu bersosialisasi dengan orang lain. Kondisi pandemi ini juga berdampak cukup besar pada perekonomian. Hal ini juga memengaruhi kondisi finansial dalam keluarga, misalnya adanya penurunan pendapatan bahkan terdapat pekerja yang di PHK dari kantor. Ataupun pekerjaan-pekerjaan yang di masa pandemi ini agaknya sulit dilakukan seperti pedagang di sekolah, tempat wisata, perhotelan, berkaitan dengan transportasi umum dan masih banyak lagi.

Tantangan lain di masa pandemi ini adalah kesulitan dalam mengatur waktu atau batas bekerja/ belajar dengan beristirahat, kurang adanya kebebasan pribadi (privacy), duka yang dialami akibat COVID 19, atau kecemasan berlebihan terkait kondisi kesehatan orang-orang terdekat, kebijakan pemerintah dan tempat bekerja yang tidak bisa di duga. Tantangan demi tantangan di masa pandemi ini juga dialami keluarga demi keluarga di Indonesia yang tidak hanya memengaruhi kondisi keuangan, kesehatan fisik namun erat sekali dengan kesehatan mental. Hal ini dikarenakan adanya kesulitan dan tantangan tersebut dapat membuat individu rentan terhadap stress dan gangguan psikologis lainnya. Oleh karena itu dibutuhkan penyebaran informasi terkait kesehatan mental bagi masyarakat secara meluas dimulai dari unit terkecil yaitu keluarga. Artinya psikoedukasi dapat menjangkau para orang tua, anak-anak dan remaja.

Pandemi ini membuat orang tua memiliki lebih banyak di rumah. Namun tidak sedikit orang tua masih belum bisa memberikan waktu khusus kepada anak-anaknya. Sebagian besar orang tua yang bekerja memberikan perhatian terbatas hanya pada pemenuhan kebutuhan fisik tetapi melupakan kebutuhan secara emosional. Anak juga membutuhkan kehangatan secara emosi, seperti perhatian dan kepedulian baik secara verbal atau tindakan langsung (Miller \& Speirs Neumeister, 2017). Adanya pandemi ini justru sebagian orang tua dapat memiliki waktu yang lebih banyak di rumah bersama anak-anak. Namun hal ini tidak menjadi jaminan bahwa dengan adanya pandemi ini orang tua memiliki kesadaran dan menjadi sebuah kesempatan untuk menjalin kedekatan secara emosional. Selain dari adanya kondisi pandemi yang membuat orang tua bekerja dari rumah atau 
terpaksa di rumahkan karena adanya efisiensi dari perusahaan. Hal tersebut tentu memiliki dampak kondisi psikis para orang tua yang tentunya berdampak pada seisi keluarga. Artinya orang tua membutuhkan pertolongan terlebih dahulu sebelum dapat menolong anak-anak mereka beradaptasi.

Di sisi lain, masa pandemi ini membuat para remaja yang sedang belajar dari rumah tak jarang merasa kesepian karena tidak bisa bertemu dengan teman-temannya, merasa tertekan karena banyaknya tugas sekolah yang harus dikerjakan tanpa teman diskusi, ditambah lagi kurang mendapatkan perhatian dari orang tua karena dianggap sudah besar. Pemaparan ini menjelaskan bahwa semua sedang beradaptasi dan menghadapi tantangannya masing-masing. Baik dari sisi orang tua masih dalam masa adaptasi pengaturan kerja di rumah sehingga tetap disibukkan pekerjaan bahkan kesulitan dalam pengaturan waktu dan masih cenderung kurang menyediakan waktu untuk anakanak mereka. Sementara anak-anak sudah bosan di rumah dan tidak bisa bebas bermain dengan temantemannya. Alhasil, pandemi ini cukup banyak memengaruhi relasi anak dengan orang tua, apakah semakin membaik atau pun dapat sebaliknya dapat memburuk.

Adanya kebutuhan narasumber untuk membagikan informasi terkait kesehatan mental dan pola asuh orang tua di masa pandemi maka Yayasan Busur Emas (YBE) berkolaborasi dengan penulis sebagai seorang psikolog dan dosen Fakultas Psikologi. YBE merupakan Yayasan yang telah lama bekerjasama dengan heartline radio sejak akhir 2014 dalam sebuah program Parenting With Heart (PWH). Program tersebut disiarkan setiap minggunya dengan berbagai narasumber baik konselor dan psikolog. Dalam periode ini, penulis ikut terlibat satu bulan satu kali terutama tema-tema terkait kesehatan mental anak dan orang tua dimasa pandemi.

Berdasarkan pemaparan diatas tujuan dari penyuluhan ini adalah memberikan edukasi pentingnya kesehatan mental dalam keluarga. Maka dari itu pengabdian masyarakat di masa pandemi ini berwujud penyuluhan secara online untuk orang tua dan anak. Adapun dua kegiatan tesebut yaitu talkshow parenting secara online di radio Heartline (100.6 FM) dan program wichat (IG Live dan webminar) terkhusus untuk menjangkau anak dan remaja agar memiliki sarana untuk "ngobrol" tentang seputar kesehatan mental bersama psikolog. Sekaligus memberikan informasi sarana untuk memberikan webminar terkait kesehatan mental dan memberikan telekonseling secara gratis bagi yang membutuhkan.

\section{METODE}

Pengabdian masyarakat diawali Kerjasama antara penulis dengan Yayasan Busur Emas (YBE) dan radio Heartline (100.6 FM) yang telah berlangsung secara terprogram dan berkelanjutan sejak tahun 2015 (Lidiawati, 2018, 2019a) Kerjasama ini dalam rangka melakukan psikoedukasi untuk para orang tua dalam bentuk talkshow bertajuk Parenting With Heart (PWH) setiap hari Sabtu pukul 07.00-08.00 WIB. Adanya pandemi maka program ini juga disiarkan melalui live streaming di Youtube Heartline radio. Selain dari psikoedukasi melalui radio dan youtube maka penulis juga membuat sarana untuk dapat berkomunikasi secara langsung dengan psikolog melalui media IG Live sehingga dapat langsung ngobrol dengan psikolog seara daring. Program IG Live ini berwujud obrolan Sabtu Siang terkait kesehatan mental dalam wadah yang Bernama WichatPsy (Waktu Indonesia Chatting Psychology) bekerja sama dengan seorang Psikolog Anak di Jerman. Bersama Wichat juga telah mengadakan webminar bertema "Pribadi yang tangguh". Selain itu, follower dapat melakukan konsultasi melalui Zoom berupa telekonseling personal jika ada yang membutuhkan. Program ini sebagai kelanjutan bahwa adanya kebutuhan informasi tentang kesehatan mental di masa pandemi ini dan dapat menampung pertanyaan ataupun usulan tema yang ingin mereka tahu.

\section{HASIL DAN PEMBAHASAN}

\section{Parenting dan kesehatan mental dimasa pandemi}

Berdasarkan survey dari 144 orang tua yang juga dilakukan oleh penulis sebelum memberikan psikoedukasi lebih lanjut terkait parenting di masa 
pandemi yang masih sedang berlangsung, diketahui bahwa para orang tua menghadapi berbagai kesulitan berkaitan dengan peran ganda sebagai orang tua dan guru. Hal ini dikarenakan para orang tua bekerja di rumah, anak belajar dari rumah juga (Lidiawati, 2020). Oleh karena itu tema-tema yang dibawakan seputar pendampingan orang tua di masa pandemi ini.

Pendampingan orang tua di masa pandemi tidak terlepas dari pemahaman parenting atau pola asuh. Pengasuhan dan cara mendidik untuk anak memang tidak memiliki sekolah formal tetapi harus dibekali dengan cara mendidik yang baik untuk anak dikemudian hari. Parenting atau lebih dikenal dengan istilah pola asuh orang tua terhadap anak. Apakah terdapat perbedaan antara pola asuh sebelum pandemi dengan di masa pandemi? Pada dasarnya pola asuh didasari dari dua dimensi yaitu adanya kehangatan kasih sayang atau juga dikenal dengan level support dan pengawasan, tuntutan/ kontrol dari orang tua. Kedua hal ini menjadi kunci penting agar cara mendidik orang tua tidak hanya menekankan salah satu saja, atau bahkan tidak melibatkan kedua dimensi tersebut (Lidiawati, 2018)

Adanya dukungan dari orang tua, kehangatan dan kasih sayang dapat diwujudkan dalam berbagai bentuk (Bartau-Rojas, AierbeBarandiaran, \& Oregui-González, 2018). Misalnya dengan adanya pujian atau apresiasi kepada anak, penghargaan atas usaha yang telah anak kerjakan, peluk hangat dan belaian kasih kepada anak dapat meningkatkan rasa percaya diri pada anak. Waktu bermain bersama dengan anak, pemberian hadiah atas prestasi dan memberikan perhatian sesuai dengan kebutuhan anak. Adanya kehangatan tentu memiliki dampak yang positif ketika diberikan dalam kondisi yang sesuai dan tidak berlebihan (Ihmeideh \& Shawareb, 2014).

Kontrol dapat berupa bimbingan dan arahan dari orang tua kepada anak. Orang tua memiliki tanggung jawab untuk memberitahu perilaku yang tepat atau sesuai dengan norma. Kerapkali orang tua memiliki persepsi yang kurang tepat dalam memberikan kontrol kepada anak, bukan protektif atau bahkan terlalu berlebihan dalam memberi batasan tetapi seharusnya dapat memberikan batasan yang jelas. Misalnya, adanya jadwal yang jelas terkait peraturan jam belajar di rumah, penggunaan gawai untuk bermain dengan bijak, kapan boleh keluar rumah, protokol kesehatan selama pandemi, dll. Dalam penerapan pemberian aturan pun orang tua perlu untuk menjelaskan kepada anak dengan baik.

Pola pengasuhan orang tua seharusnya konsisten antara ayah dan ibu, serta melibatkan adanya kontrol dan kehangatan dalam mengasuh anak-anak mereka (Bartau-Rojas et al., 2018; Ihmeideh \& Shawareb, 2014; Miller \& Speirs Neumeister, 2017). Pola asuh yang memberikan kasih sayang dan kontrol secara seimbang dikenal dengan istilah autoritatif. Gaya pengasuhan ini anak dalam kondisi yang baik secara fisik dan psikologis. Namun pada kenyataannya banyak kasus pada anak diakibatkan karena pola asuh yang tidak konsisten, ataupun komponen pengasuhan yang tidak seimbang. Misalnya ayah kerapkali lebih banyak memberikan tuntutan sedangkan ibu memberikan kelonggaran atau sebaliknya. Tipe gaya pengasuhan yang berlebihan dalam pengawasan ini pun dapat mengakibatkan kondisi psikis kurang baik. Selain itu, tidak sedikit anak yang diabaikan oleh orang tuanya. Beberapa alasan pengabaian kepada anak terjadi seperti karena orang tua sibuk bekerja, bercerai, ataupun ketidakmatangan emosional orang tua (Lidiawati, 2018)

Disisi lain, kerapkali orangtua menjadi frustasi menghadapi tingkah laku buruk pada anakanak sehari-hari. Apalagi dalam proses belajar secara online. Anak-anak kurang perhatian, sulit fokus dan kerapkali tidak mengerjakan tugasnya. Ketika perilaku ini muncul orang tua kerapkali memberikan konsekuensi yang tidak menyenangkan padahal ingin meningkatkan perilaku belajar. Hal ini tentu berkebalikan dengan teori pembentukan perilaku. Jika orang tua ingin meningkatkan perilaku seharusnya dengan memberikan penguatan (reinforcement), sebaliknya jika ingin menurunkan atau melemahkan perilaku maka harus diberikan konsekuesi yang tidak menyenangkan bisa berupa teguran atau mengambil hak anak untuk bermain gadget selama 1 hari, memotong uang jajan. Selain itu, dimasa pandemi ini penting untuk memberikan edukasi kepada anak agar mampu belajar secara mandiri. Artinya anak perlu meningkatkan kemampuan pola belajar mandiri (Alnafea \& Curtis, 
2017; Inam, Nomaan, \& Abiodullah, 2016). Hal ini sejalan dengan penelitian bahwa self- regulated learning diperlukan agar siswa dapat terlibat dalam proses pembelajaran secara online (Lidiawati \& Helsa, 2021).

Penerapan pola asuh yang memberikan kehangatan dan kontrol atau tuntutan yang sepadan tentu harapan semua orang tua. Orang tua membutuhkan informasi dan solusi praktis agar dapat diterapkan pada keluarga masing-masing. Hal ini yang menjadi dasar pemikiran bahwa program penyuluhan terkait parenting masih tetap dibutuhkan. Hal ini mengingat adanya kebutuhan informasi yang tepat, sederhana dan praktis namun tetap berdasarkan penelitian ilmiah.

Pada zaman sekarang tentunya informasi sangat mudah didapatkan melalui media sosial yang semakin banyak dinikmati semua kalangan, salah satunya adalah melalui youtube dan penyiaran di radio. Penyiaran radio heartline radio (100.6 FM) juga ditayangkan melalui live streaming youtube sehingga memudahkan orang tua untuk mengulangi materi apabila terlewat dari jam siaran. Program ini mengangkat tema Parenting With Heart $(P W H)$ artinya pola pengasuhan juga melibatkan kedekatan dan kelekatan antara anak dengan orang tua.

Adapun setiap tema yang diangkat memiliki latar belakang, alasan tema tersebut dibahas dalam program PWH. Program ini dapat dikategorikan sebagai penyuluhan yang dilakukan melalui penyiaran radio dengan tujuan yang sama yaitu memberikan informasi dan membantu para orang tua lebih memahami anak-anak mereka dan permasalahannya dengan memperhatikan tahap perkembangan anak apalagi di masa pembelajaran online karena pandemi masih sedang berlangsung. Karena setiap anak berbeda satu dengan yang lainnya, demikian juga permasalahan anak memiliki solusi yang berbeda sesuai dengan keunikan masing-masing kondisi anak dan keluarga(Hagan et al., 2012). Perbedaan kondisi pandemic ini membuat permasalahan yang berbeda dan kerap menguras energi psikis dalam mendampingi anak belajar di rumah. Oleh karena itu diperlukan informasi terkini dan disesuaikan dengan kondisi.

Adapun tema-tema yang diangkat merupakan hal-hal yang terjadi dan kerap kali dihadapi oleh orang tua dimasa pandemi ini. Berikut ini adalah beberapa topik yang akan disampaikan periode Januari sd Juli 2021.

Tabel. 1. Tema Parenting With Heart

\begin{tabular}{lll}
\hline Bulan & Judul (Tema) Talkshow & \\
\hline 9 Januari & $\begin{array}{l}\text { Pentingnya mendampingi balita } \\
\text { bermain }\end{array}$ \\
\hline 13 Maret & $\begin{array}{l}\text { Pentingnya Pendidikan Seksualitas } \\
\text { pada anak }\end{array}$ \\
\hline 24 April & Seni Berkomunikasi dengan remaja \\
\hline 29 Mei & $\begin{array}{l}\text { Jurusan yang tepat: Minat Anak Vs } \\
\text { Minat Orang tua }\end{array}$ \\
\hline 5 Juni & Waspadai Helicopter Parenting \\
\hline 10 Juli & $\begin{array}{l}\text { Mendampingi Remaja menghadapi } \\
\text { stress di masa pandemi }\end{array}$ \\
\hline
\end{tabular}

Berikut ini merupakan contoh flyer yang disebarkan sebelum siaran dan pada saat tampilan awal siaran di youtube setiap bulannya.

Gambar 1. Bulan Januari

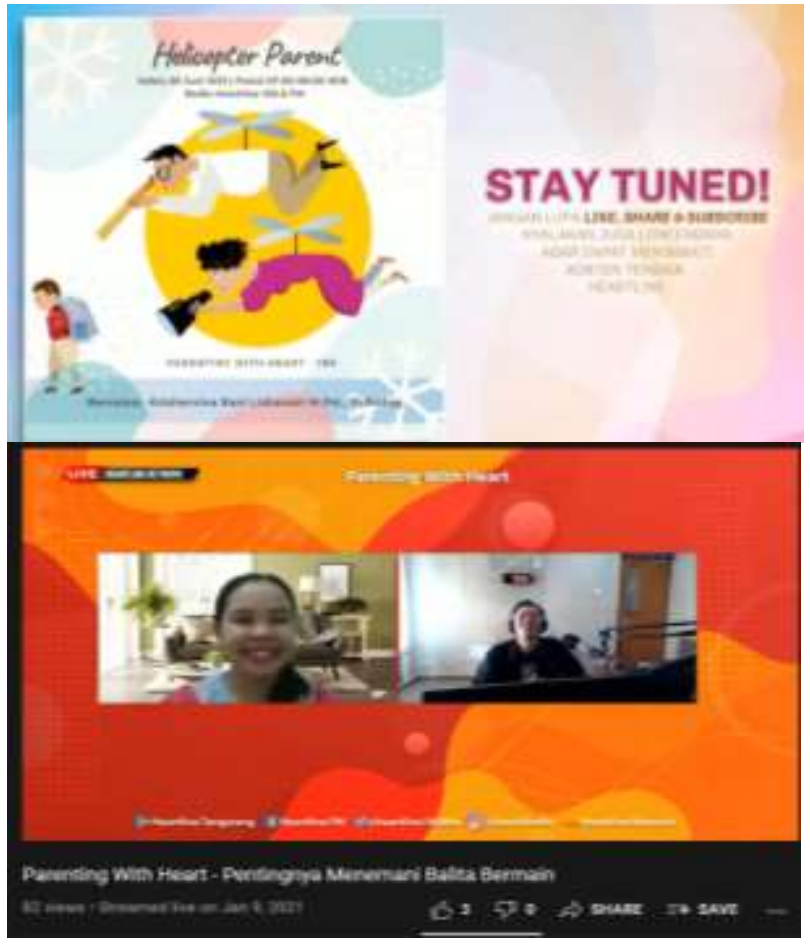


Gambar 2. Bulan Maret
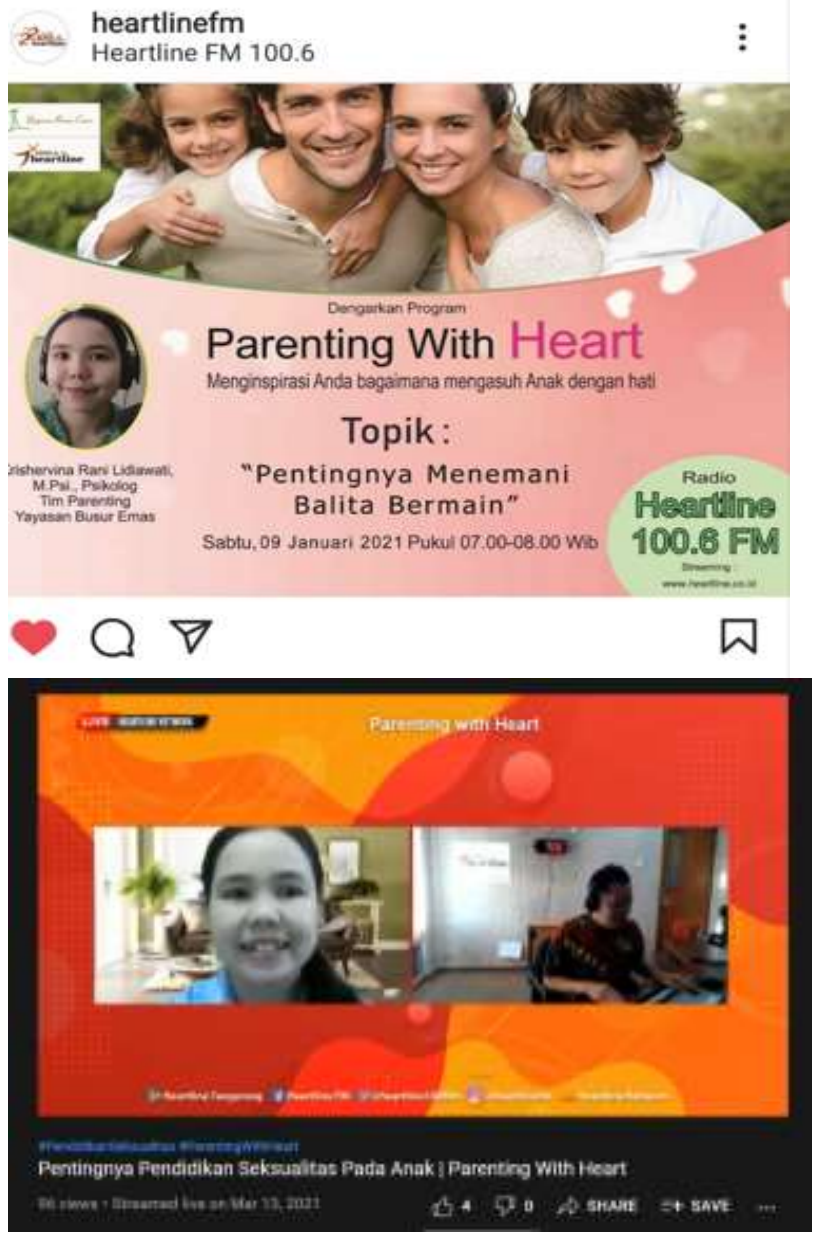

Gambar 3. Bulan Mei

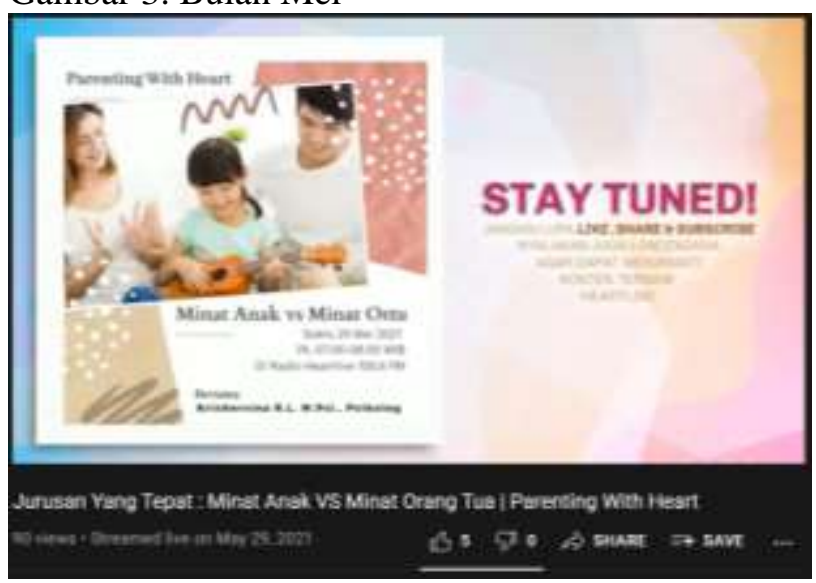

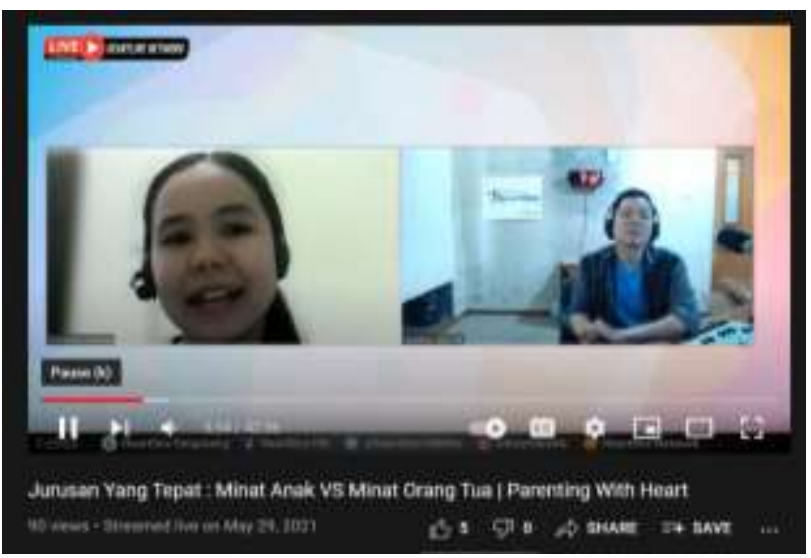

Gambar 4. Bulan Juni

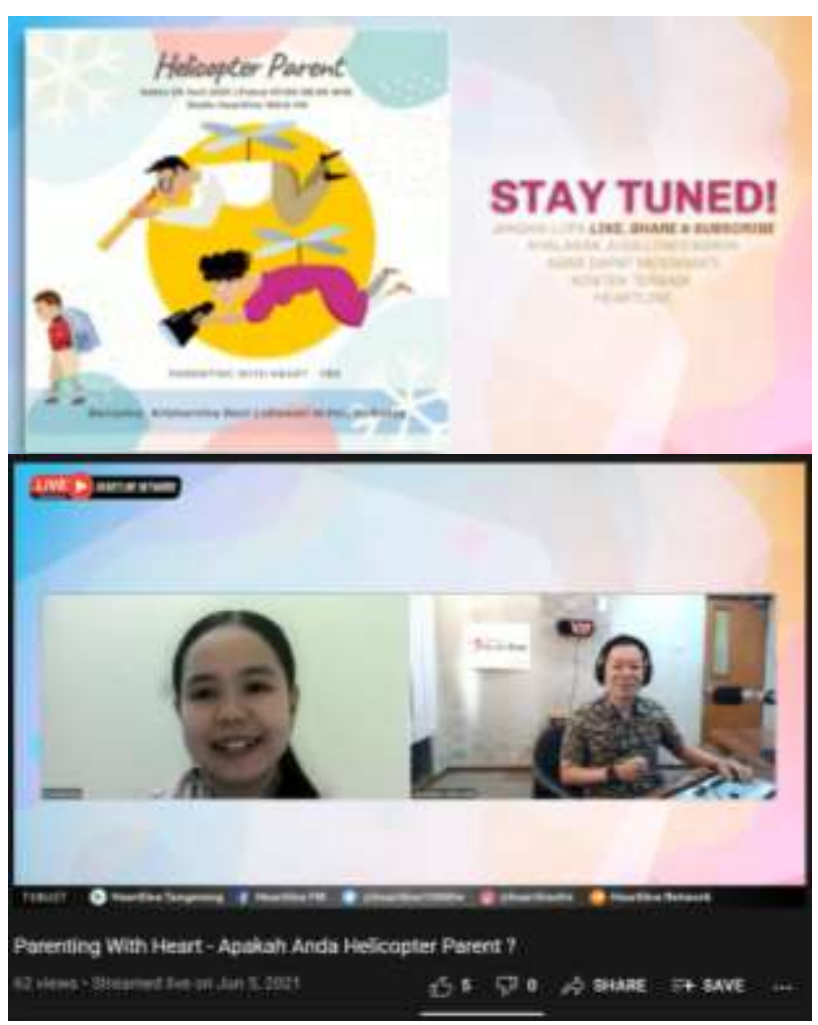




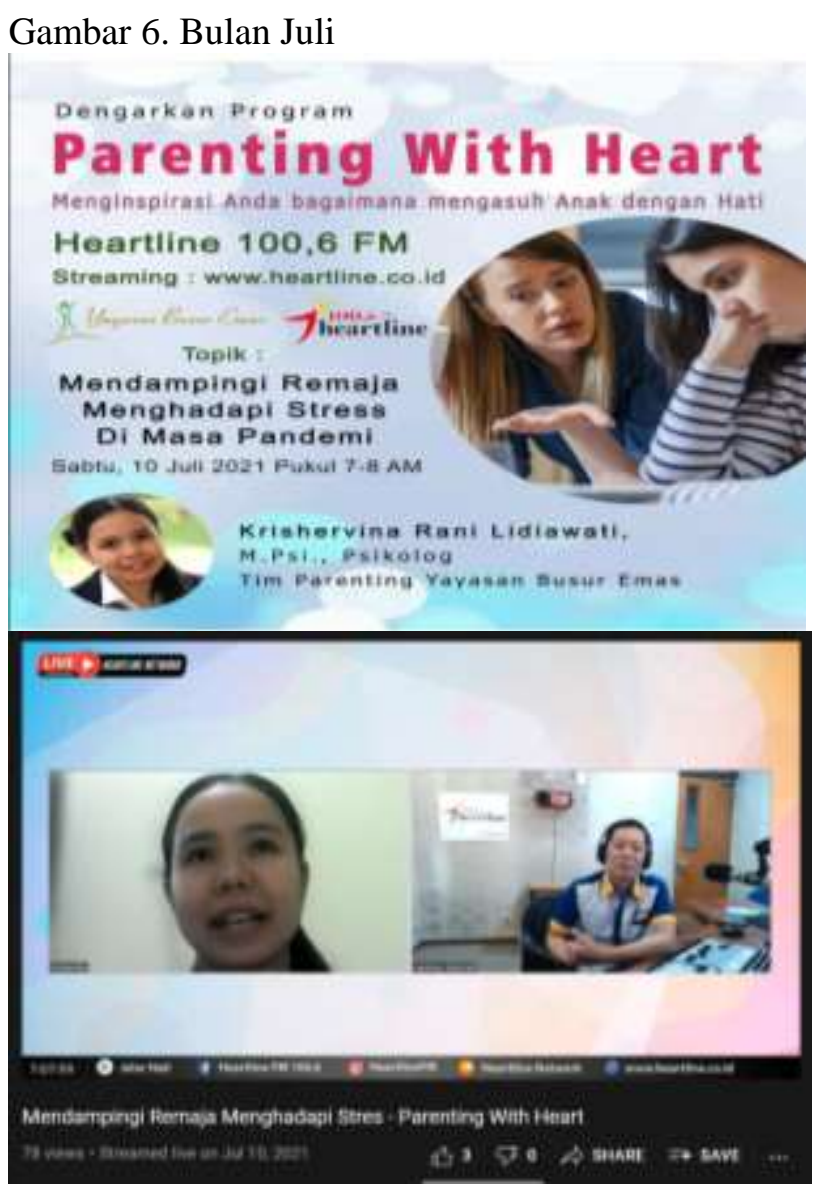

Pada tema pertama dikhususkan untuk orang tua yang memiliki anak balita yaitu usia 0 sampai lima tahun. Pada tema ini dikhususkan untuk usia 3-5 tahun sehingga lebih spesifik tahap perkembangannya. Anak direntang usia ini menghabiskan sebagian besar waktunya untuk bermain. Bermain merupakan kebutuhan utama mereka sehingga dapat mengembangkan kemampuan secara fisik, kognitif dan psikososial secara optimal. Mereka butuh bergerak, ekplorasi dan banyak aktivitas. Namun situasi pandemi memaksa tempat bermain anak di tutup untuk menghindari penularan Covid 19. Sekolah Taman Kanak-kanak pun harus melalui online. Oleh karena itu, peran orang tua dalam mendampingi anak bermain di usia ini sangat penting agar pertumbuhan mereka tetap optimal meski terbatas bermain di rumah. Tema ini membahas pentingnya bermain, manfaat bermain, hal-hal yang harus diperhatikan dalam bermain, peran orang tua dalam bermain dan tips bermain dengan anak di masa pandemi dengan kreatif namun tetap edukatif.

Tema kedua yaitu pentingnya pendidikan seksualitas pada anak. Pendidikan seksualitas seharusnya diberikan oleh orang tua. Hal ini dikarenakan, rumah adalah tempat pertama kali anak belajar value yang nantinya akan membantu anak menetukan sikap dan perilakunya dalam masyarakat termasuk terkait seksualitas. Sex education atau pendidikan seks untuk anak- anak dan remaja saat ini menjadi hal yang penting untuk dapat dilaksanakan dimulai dari keluarga apalagi selama pandemi yang hampir tiap hari terpapar dengan informasi di gawai. Pendidikan dan informasi yang benar mengenai seks merupakan dasar bagi anak-anak dan remaja untuk dapat berperilaku dan bertindak benar dalam mengambil keputusan terkait perilaku seksual dalam hidupnya.

Pada tema ini diberikan pengertian pendidikan seskualitas dalam arti luas. Seksualitas meliputi berbagai aspek yang berkaitan dengan seks, yaitu aspek biologik, orientasi, nilai sosiokultural dan moral, serta perilaku. Pendidikan seksualitas dapat mencegah perilaku beresiko, perilaku seks bebas, kehamilan yang tidak diinginkan, aborsi, pemerkosaan hingga penularan penyakit seksual. Selain itu diberikan informasi tujuan dan fungsi pendidikan seksualitas pada anak sejak dini. Lalu diberikan hal-hal apa saja yang perlu di sampaikan dan tips pemberian edukasi yang mudah dimengerti oleh anak-anak.

Tema ketiga berkaitan dengan minat dan bakat anak yaitu jurusan yang tepat: minat anak vs minat orang tua. Tema ini diangkat terkait kebutuhan anak SMA yang harus memilih jurusan yang tepat atau hanya sekedar mengikuti kemauan orang tua. Di tengah pandemi ini, remaja memiliki ruang ekplorasi yang terbatas sehingga seharusnya orang tua dapat membantu anak dalam membuka wawasan. Artinya bukan sebaliknya justru menambah beban agar anak memaksakan minat orang tua. Pembahasan seputar dampak dari pemaksaan dan terkait kesehatan mental remaja yang tertekan akibat adanya tuntutan orang tua yang tidak terpenuhi. 
Pada bulan Mei, tema yang dibawakan sangat relevan dengan kondisi pandemi ini yaitu seni berkomunikasi dengan remaja. Pada situasi pandemi ini adanya pembatasan jarak membuat remaja jarang bersosialisasi dengan temannya, komunikasi hanya terbatas secara virtual, dan tak jarang beberapa remaja menjadi sulit bergaul. Artinya penting untuk orang tua memahami remaja yang memiliki kebutuhan untuk didengarkan dan memahami cara berkomunikasi dengan anak remajanya tanpa bertengkar. Dalam tema ini belajar tentang tips singkat 3 hal yang perlu diperhatikan yaitu "What they say, How to say it, and Listen carefully". Tips ini mengajar orang tua untuk memahami, apa yang dikatakan remaja, cara untuk menyampaikan nasehat kepada remaja dan jangan lupa memberikan kesempatan para remaja untuk bercerita, orang tua menjadi pendengar dan bukan penasehat.

Tema berikutnya adalah waspadai Helicopter Parenting (HP). Tipe parenting tersebut merupakan tipe yang mungkin terjadi dimasa pandemi ini dikarenakan orang tua terlalu menekankan kontrol yang berlebihan (Ashdown \& Faherty, 2015; Bradley-Geist \& Olson-Buchanan, 2014). Berdasarkan penelitian, pola asuh ini cenderung membuat anak cenderung sulit mengembangkan kemampuan dalam pemecahan masalah, resilient dan kemandirian (Ashdown \& Faherty, 2015). Padahal di masa pandemi ini yang dibutuhkan adalah kemampuan untuk mandiri, kreatif, memecahkan masalah dan juga gigih dalam mengerjakan tugas-tugas meski tidak di awasi oleh orang tua atau guru. Oleh karena itu, orang tua perlu belajar untuk memahami agar tetap memberikan ruang dan kesempatan pada anak untuk bertanggung jawab sekecil apapun di rumah.

Bulan Juli tema yang dibawakan adalah mendampingi remaja menghadapi stres di masa pandemi. Tema ini membicarakan tiga hal yaitu definisi stres, penyebab stres pada remaja, tips mendampingi remaja di masa pandemi ini. Latar belakang dari tema ini adalah pentingnya orang tua memahami tugas perkembangan remaja dan stress yang dihadapi remaja. Orang tua kerapkali sulit untuk bersahabat dengan remaja sehingga kondisi pandemi ini dapat berdampak buruk namun juga berdampak baik dalam relasi orang tua dengan remaja. Hal ini dikarenakan semakin banyak waktu bertemu dengan orang tua dengan remaja, seharusnya dapat dimanfaatkan untuk berdiskusi bukan untuk berdebat karena perbedaan persepsi.

\section{Kesehatan Mental dan Remaja}

Informasi terkait kesehatan mental tidak hanya untuk orang tua. Namun diperlukan untuk anak-anak dan remajanya. Oleh karena itu, penulis berinisiasi untuk membentuk wadah bagi para remaja. Penulis bekerjasama dengan seorang psikolog di Jerman membentuk satu wadah "Waktu Indonesia Chatting (WiChat)" di melalui platform Instagram @Wichat.Psy. Program WiChat ini bertujuan untuk memberikan edukasi kesehatan mental yang sifatnya "Ngobrol Santai di Sabtu Siang" tetapi bermanfaat terutama bagi remaja. Berdasarkan WHO, kesehatan mental meliputi tiga dimensi yaitu kemampuan beradaptasi dengan stress, tetap berfungsi dan berkontribusi bagi lingkungan atau masyarakat. Pada masa pandemi ini tentu berbagai tantangan dan kesulitan kerapkali menggoncang kondisi psikis individu. Adanya pandemi membuat semua orang terbatas dalam melakukan aktivitas. Termasuk pada anak-anak dan remaja yang seharusnya bisa bermain dan sekolah di luar rumah bersama teman-temannya tetapi hanya bisa bertatapan secara online.

Padahal remaja senang sekali mencurahkan hati kepada teman-temannya. Hal ini menjadi salah satu program yang diberikan yaitu open mic sehingga follower dapat bertanya terkait tema ataupun mengusulkan tema yang ingin dibawakan pada obrolan Sabtu siang yang dilakukan dua minggu sekali secara Live di Instagram. WiChat juga memberikan layanan telekonseling dengan perjanjian sebelumnya. Selain itu, WiChat juga telah melakukan webminar. Salah satu webminar yang telah dilaksanakan bertema "pribadi yang tangguh".

Webminar ini membawakan tema pentingnya menjadi pribadi yang tangguh apalagi di masa pandemi ini. Dengan adanya webminar tentang pribadi yang tangguh dapat memberikan informasi terkait sifat dan cara orang untuk resilient dan menjadi "gritty person". Masa pandemi ini 
diperlukan pribadi-pribadi yang tangguh. Baik orang tua dan anak membutuhkan kemampuan bangkit dari kegagalan yang dikenal dengan istilah resiliensi. Resiliensi merupakan kualitas dalam diri seseorang mencakup kompetensi sosial, memecahkan masalah, kemandirian dan optimisme yang memungkinkan untuk berhasil beradaptasi, berkembang meskipun menghadapi resiko dan kesulitan (Mcintyre \& Member, 2014). Resiliensi kerapkali di identikan dengan kemampuan seseorang untuk dapat bangkit dari kegagalan demi kegagalan.Hal ini menunjukkan bahwa pola asuh orang tua di masa pandemi yang serba tidak menentu, banyak perubahan dan membutuhkan kemampuan adaptasi. Termasuk para orang tua yang mau tidak mau perlu belajar cara mengasuh anak agar memiliki ketahanan di tengah kesulitan yang ada.

Gritty person yaitu orang yang memiliki grit atau gigih. Tentunya bahasannya disesuaikan dengan konteks gigih dan tekun di masa pandemi ini. Trait grit menunjukkan lebih menentukan suksesnya seseorang dimasa yang akan datang. Grit didefinisikan adanya kegigihan dan adanya passion dalam jangka waktu yang lama. Seseorang mampu bertahan mengatasi kebosanan dan tetap fokus pada tujuan (Duckworth, Peterson, Matthews, \& Kelly, 2007). Grit merupakan sifat pribadi tangguh yang mau tetap tekun dan bertahan dalam waktu yang lama (Lidiawati, 2019b). Masa pandemi Covid 19 ini telah berlangsung lebih dari satu tahun dan masih sedang berlangsung. Oleh karenanya penting bagi orang tua untuk dapat mendidik anak dalam menghadapi kegagalan dalam hidup dan menghadapi ketidakpastian dalam masa pandemi ini. Mereka harus terus mampu bertahan dan tetap fokus mengerjakan apa yang seharusnya dikerjakan. Bahkan ketika menghadapi kegagalan, tidak mudah menyerah dan tetap memiliki daya juang untuk belajar secara mandiri meski belajar di rumah.

Akhir kata, kegiatan pengabdian masyarakat yaitu talk-show dilakukan secara terprogram terkait parenting dan masalah anak dan remaja. Hal ini tentunya sejalan dengan salah satu misi Fakultas Psikologi UPH yaitu pengembangan karakter. Dengan adanya pengetahuan dan pemahaman yang benar tentang bagaimana mendidik anak-anak mereka maka diharapkan anakanak dapat bertumbuh dan berkembang menjadi pribadi yang sehat secara fisik, emosi dan spiritual. Apalagi di masa pandemi ini orang tua perlu untuk memperhatikan kesehatan mental anak-anak agar tetap memiliki kualitas pribadi yang tangguh. Hal ini dapat dimulai dari para orang tua dengan memiliki pengetahuan yang benar tentang parenting atau pola asuh yang tepat pada anak sehingga dapat mencegah permasalahan-permasalah pada anak secara psikologis (Baker, Sanders, \& Morawska, 2017). Bagi remaja mereka dapat belajar juga melatih diri untuk menjadi pribadi yang tangguh dengan mengembangkan ketrampilan sosial dan belajar dari kegagalan.

\section{KESIMPULAN}

Kegiatan penyuluhan talkshow parenting telah dilakukan dengan baik dengan mengangkat tema yang mempertimbangkan keragaman tingkat perkembangan anak. Dari usia balita hingga remaja. Informasi yang disampaikan berguna baik untuk orang tua, pendidik, serta para remaja. Parenting bukan tugas yang mudah bagi para orang tua. Terutama untuk dapat menciptakan suasana nyaman apalagi ditengah pandemi. Adanya penyuluhan parenting ini telah memberikan manfaat bagi orang tua. Beberapa manfaat yang di dapat yaitu informasi/ fenomena terkini, berbagai pengalaman orang tua, penelitian terbaru dan saran praktis yang diberikan terutama dalam menjaga kesehatan mental diri sendiri dan keluarga.

Beberapa hambatan dalam program PWH ini adalah masalah teknis dan durasi talkshow. Masalah teknis, seperti koneksi dan suara terkadang kurang jernih. Namun, saat ini telah diantisipasi dengan pindahnya ke provider yang baru dan kecepatan yang telah ditingkatkan maka diharapkan audio dan video dapat berkualitas baik. Masalah kedua adalah terkait durasi talkshow. Hal ini terkait dengan beberapa tema membutuhkan durasi yang lebih panjang dan akan lebih baik jika terbagi dalam dua kali talkshow dikemudian hari. Selain itu, dapat dilakukan program seminar parenting sehingga lebih banyak interaksi dan diskusi antara orang tua dan narasumber. Namun adanya kebutuhan tematema parenting yang erat terkait kesehatan mental 
maka program ini tetap dilanjutkan dengan mengusung tema-tema yang dibutuhkan oleh masyarakat luas. Apalagi dengan adanya penyiaran yang saat ini tidak terbatas wilayah karena dapat dinikmati melalui youtube.

Selain itu, perlu diadakan semiar dan adanya artikel ilmiah yang dapat menjadi sumber informasi dalam mendampingi anak-anaknya selama masa pandemi ini karena tema relevan dengan kondisi pandemi. Implikasi yang lain adalah penting juga untuk memberikan wadah bukan hanya kepada orang tua namun bagi anak-anak untuk belajar tentang kesehatan mental. Artinya program WiChat.Psy dapat terus ditingkatkan dan diharapkan dapat memberikan informasi serta sarana untuk melakukan konsultasi/ obrolan santai berkaitan kesehatan mental para remaja.

\section{UCAPAN TERIMAKASIH}

Ucapan terimakasih disampaikan kepada mitra pengabdian masyarakat yaitu Yayasan Busur Emas, Radio Heartline (100.6 FM). Ucapan terimakasih juga disampaikan kepada Fakultas Psikologi UPH dan LPPM yang memberikan dukungan sehingga pengabdian masyarakat ini dapat terlaksana dengan baik dengan nomor PM125-M/FPsi/VII/2020.

\section{REFERENSI}

Alnafea, T., \& Curtis, D. D. (2017). Influence of mothers 'parenting styles on self-regulated academic learning among Saudi primary school students Self-regulated learning. 27(3).

Ang, C. S., Tan, J. P., \& Fam, S. Y. (2016). Psychometric Properties of the Training Parenting Style Scale in a Malaysian Sample of Adolescents: Factor Analysis, Internal Consistency, and Measurement Invariance. Journal of Child and Family Studies, 25(5), 1505-1514. https://doi.org/10.1007/s10826015-0333-1

Ashdown, B. K., \& Faherty, A. N. (2015). Excessive hovering: Helicopter parenting and its consequences. PsycCRITIQUES, 60(42). https://doi.org/10.1037/a0039662

Baker, S., Sanders, M. R., \& Morawska, A. (2017). Who Uses Online Parenting Support? A Cross-Sectional Survey Exploring Australian Parents' Internet Use for Parenting. Journal of Child and Family Studies, 26(3), 916-927. https://doi.org/10.1007/s10826-016-0608-1

Bartau-Rojas, I., Aierbe-Barandiaran, A., \& OreguiGonzález, E. (2018). Parental mediation of the Internet use of Primary students: Beliefs, strategies and difficulties. Comunicar, 26(54), 71-79. https://doi.org/10.3916/C54-2018-07

Bradley-Geist, J. C., \& Olson-Buchanan, J. B. (2014). Helicopter parents: An examination of the correlates of over-parenting of college students. Education and Training, 56(4), 314328. https://doi.org/10.1108/ET-10-2012-0096

Duckworth, A. L., Peterson, C., Matthews, M. D., \& Kelly, D. R. (2007). Grit: Perseverance and Passion for Long-Term Goals. Journal of Personality and Social Psychology, 92(6), 1087-1101. https://doi.org/10.1037/00223514.92.6.1087

Hagan, M. J., Tein, J. Y., Sandler, I. N., Wolchik, S. A., Ayers, T. S., \& Luecken, L. J. (2012). Strengthening Effective Parenting Practices Over the Long Term: Effects of a Preventive Intervention for Parentally Bereaved Families. Journal of Clinical Child and Adolescent Psychology, 41(2), 177-188. https://doi.org/10.1080/15374416.2012.65199 6

Ihmeideh, F. M., \& Shawareb, A. A. (2014). The association between internet parenting styles and childrens use of the internet at home. Journal of Research in Childhood Education, 28(4), 411-425. https://doi.org/10.1080/02568543.2014.94472 3

Inam, A., Nomaan, S., \& Abiodullah, M. (2016). Parents' Parenting Styles and Academic Achievement of Underachievement and High Achievers at Middle School Level. Bulleting of Education and Research, 38(1), 57-74.

Lidiawati, K. R. (2018). Penyuluhan Parenting Melalui Program Talk-Show Di Radio. Prosiding PKM-CSR, 1, 1064-1074. 
Lidiawati, K. R. (2019). Penyuluhan Cara Menghadapi Generasi Millenial Bekerjasama dengan Sekolah, Gereja dan Radio. Prosiding PKM-CSRPKM CSR, 2, 848-854.

Lidiawati, K. R. (2020). Sukses Mendampingi Anak Belajar Mandiri di Masa. Buletin KPIN, 6(18). https://doi.org/ISSN 2447-1686

Lidiawati, K. R, \& Helsa. (2021). Online learning during Covid-19 pandemic: How selfregulated learning strategies impact student engagement? 14(1), 1-10. https://doi.org/10.30813/psibernetika.v14i1.25 70

Lidiawati, K.R, \& Helsa. (2021). Online learning during Covid-19 pandemic: How selfregulated learning strategies impact student engagement? 14(1), 1-10. https://doi.org/10.30813/psibernetika.v14i1.25
70

Lidiawati, Krishervina. R. (2019). Melatih Anak Memiliki Daya Juang. Buletin KPIN, (February). Retrieved from https://buletin.kpin.org/index.php/arsip-artikel/374-grit

Mcintyre, S., \& Member, C. (2014). Can Resiliency in Black Adolescent Males Be Correlated With Parenting Style?

Miller, A. L., \& Speirs Neumeister, K. L. (2017). The Influence of Personality, Parenting Styles, and Perfectionism on Performance Goal Orientation in High Ability Students. Journal of Advanced Academics, 28(4), 313-344. https://doi.org/10.1177/1932202X17730567

Ritter, E. N. (2005). Parenting Styles: Their Impact on the development of adolescent resiliency.

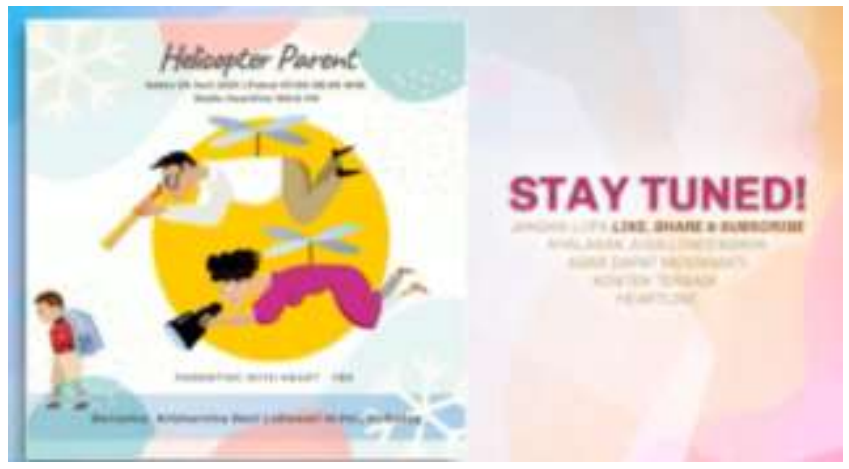

